\title{
Competence of Physical Education, Sports and Health Teachers in Elementary Schools of Lubuk Sikaping
}

\author{
Muhammed Hangga Razaak *, Nurul Ehsan, Atradinal \\ Sport Education Program \\ Faculty of Sport Science \\ Padang State University \\ Padang, Indonesia \\ $\underline{\text { hanggamrazak@gmail.com }}$
}

\begin{abstract}
The purpose of this research is to describe the competence of elementary school teachers in the Lubuk Sikaping Pasaman Regency. This research classified into descriptive research using a questionnaire to collect the data. This study involved 20 teachers. Data were analyzed using descriptive analysis technique formula is $P=F / N x 100 \%$. The result showed the competence of physical education, sport and health teachers in elementary school Sikaping was $71.17 \%$ achievement level is on good category, consist of pedagogic competence is $67.00 \%$ in the excellent category, personality competence is $65.89 \%$ in the excellent category, social competence is $64.78 \%$ in the excellent category, and professional competence is $61.67 \%$ in the excellent category.
\end{abstract}

Keyword-Competence, teachers, elementary schools

\section{INTRODUCTION}

Education is essentially a process of nation building keseluruan, where education is instrumental in developing aspects of life, especially in a period of reform that completely trasnsparan today. Education is essentially a role in educating the nation whose goal is to improve quality of Indonesian human.

National Education serves to develop the ability and character development and civilization dignified nation in the context of the intellectual life of the nation, is aimed at developing students' potentials in order to become a man of faith and fear of God Almighty, noble, healthy, knowledgeable, skilled, creative, independent and become citizens of a democratic and responsible[1].

Guided by the quote above, it means the national education useful to develop skills and form attitudes that are very important in the life of society, education is not only very important for the individual, but also very important for the national life. In the national education goals explained that a democratic life depends on the participation of citizens are intelligent and responsible

It lies in the quality of education received by children and youths, one of education is elementary school (SD), SD is an institution that provided supplies to the students to be able to continue their education kejenjang higher, when viewed subjects there in elementary school curriculum can be grouped into general education programs, educational program of academic and vocational education programs.

According to Sanjaya (2008) in [2] educational learning physical sports and student health in school is influenced by many factor, diant aranya; Teacher skills physical education and sports health, students, facilities and infrastructure and environmental factors. One of the subjects contained in the general education program is a physical education (physical education). Physical Education and Sport is essentially a process of education that utilizes physical activity (physical) exercise to produce a change in the quality of the individual, both in terms of physical, mental and emotional. Philosophically regarding physical education is the most important part of the overall education.

Teacher is a profession, which means a position that requires special skills as a teacher and can not be done by anyone outside the field of education.

A teacher must have a good performance in carrying out the duties and responsibilities that must be planning lessons by a teacher, which is a device preparation curriculum that will support teachers in teaching. As planned annual program, the semester program, syllabus, lesson plan, enrichment and remedial programs. This is a routine task that must be planned teachers in teaching, with careful planning would be more fruitful learning objectives to be achieved.

To achieve the learning objectives to be achieved by the teachers and a teacher must have a good performance in learning in school. The factors that affect the performance of teachers in the learning process in schools, among other things: mental attitude, education, management leadership, competence and achievement opportunity. Of the several factors that affect the performance of the teacher performance factors are most important teacher to be ruled by teachers in school, and these factors are factors of teacher competence.

Teacher competence is the combination of personal ability, scientific, technological, social, and spiritual are kafah form teacher professional standards of competence includes the mastery of materials, understanding of learners, educational learning, personal development and professionalism. 
Pedagogical competence is the basis for teachers to teach and educate students in the classroom. Within the competence of the teacher, the teacher always face to face with students who definitely need the knowledge, skills, and attitudes to face life in the future. For the role of the teacher is very large and important in demanding responsibility to be individual teachers have extensive knowledge, diverse skills, and morale high.

Personal competence is the ability beraklak personality noble, stable, wise, exemplary, evaluating its own performance, to develop themselves, and religious. In this case the teacher will be able to change the behavior of learners if he had been a good man, so the teacher will be a good example for their students. For that a teacher must have a good personality competency for himself and the students in the learning process in schools.

Social competence is the ability of educators as part of the community to communicate orally and in writing, using information and communication technology functionally interact effectively with pesertadidik and mingle politely with the surrounding community. To the teacher is very important social skills mastered by teachers to achieve educational goals in teaching and educating students.

Professional competence is the knowledge and skills learned by the teacher while in college with her condition began to teach. As an example that a person's success is not only influenced by the intellect but also influenced by emotional and spiritual intelligence even greater than the effect of both intellectual intelligence. So teachers must have the intelligence capability in teaching student at the school.

Competence is a set of knowledge, skills and behaviors that should be owned, lived, and overpoweredby teachers in implementing the tasks of professionalism. Competence in Indonesian is the uptake of the English language, which means skill competence or ability. Defines competence as a full set of intelligent action and responsibility that I owned a person as a condition for deemed capable by the public in carrying out tasks in accordance with the particular job[3].

the professionalism of teachers is a necessity in creating a knowledge-based school, which is an understanding of the of learning, curriculum and human development, including learning style[4]. In general, the school that teachers have the professional competence will apply learning (to do) to replace a way of teaching where the teacher only spoke and pupils only listen.

\section{RESEARCH METHODOLOGY}

This study aims to determine the level of competence of primary school teachers Kecematan Lubuk Sikaping se. Which consists of pedagogical, personality, social, and professional. Thus, this study is descriptive, the research aims to reveal things as they are, as proposed by This research aims to create a hostage in a systematic, factual and accurate information on the facts and the properties certain populations "[5]. In connection with it in this study described is about the level of competence of elementary school teachers throughout the District Lubuk Sikaping. While the sample in this study is Principal and one teacher Kecematan Lubuk Sikaping elementary schools who are in group 5 and group 6 totaling 10 Elementary School. "is most members of the population sample taken using sampling techniques"[4]. Based on the above opinion, a sample is the most number of characteristics possessed by the population by sampling.teknik taking the sample using purposive sampling, which is a technique used when members of the specially selected samples based on objective research. To obtain the data is done filling the questionnaire. The data analysis technique is descriptive analysis. is the frequency (descriptive statistics) to the percentage calculation.

\section{RESULT}

The data collected in this study to be verified first. It is intended to check the completeness of the data from each instrument given to respondents. Based on the results of verification of the number of samples in this study as many as 20 people were given a questionnaire. after being examined only 18 questionnaires that can be restored, a questionnaire was not returned due to questionnaire respondents filled in at home, so that researchers respondents difficult to meet because the home, school respondents distant and difficult to contact. therefore the sample set as many as 18 people.

\section{Pedagogic Competence}

Based on data obtained from 18 respondents including principal and one of the school teachers, the pedagogical competence indicator obtained a total score of 150 with relative frequency $(22.39 \%)$ stated strongly agree, total score of 320 with relative frequency $(47.76 \%)$ agreed, then with a total score of 180 with relative frequency $(26.87 \%)$ expressed a neutral / doubt, the total score of 20 with relative frequency $(2.99 \%)$ disagree, and with a total score of 0 with relative frequency $(0 \%)$ stated strongly disagree .

Table 1. Competence Pedagogy

\begin{tabular}{|c|c|c|c|c|}
\hline answer & $\begin{array}{c}\text { Score } \\
(\mathrm{X})\end{array}$ & $\mathrm{F}$ & $\mathrm{FX}$ & $\begin{array}{c}\text { Relative } \\
\text { frequency }\end{array}$ \\
\hline Strongly agree & 5 & 30 & 150 & 22.39 \\
\hline Agree & 4 & 80 & 320 & 47.76 \\
\hline Neutral / Ragu & 3 & 60 & 180 & 26.87 \\
\hline Disagree & 2 & 10 & 20 & 2.99 \\
\hline Strongly Disagree & 1 & 0 & 0 & 0,00 \\
\hline \multicolumn{2}{|c|}{ amount } & 180 & 670 & 100 \\
\hline
\end{tabular}

\section{Competence Personality}

Based on data obtained from 18 respondents including principal and one of the school teachers, the pedagogical competence indicator obtained total score of 125 with relative frequency $(19.97 \%)$ stated strongly agree, total score of 248 with relative frequency (39.62\%) agreed, then the total score of 216 with relative frequency 
(34.50\%) expressed a neutral / doubt, the total score of 32 with relative frequency $(5.11 \%)$ disagree, and with a total score of 5 with relative frequency $(0,80 \%)$ stated strongly disagree.

Table 2. Competence Personality

\begin{tabular}{|l|c|c|c|c|}
\hline \multicolumn{1}{|c|}{ answer } & $\begin{array}{c}\text { Score } \\
(\mathrm{X})\end{array}$ & $\mathrm{F}$ & $\mathrm{FX}$ & $\begin{array}{c}\text { Relative } \\
\text { frequency }\end{array}$ \\
\hline Strongly agree & 5 & 25 & 125 & 19.97 \\
\hline Agree & 4 & 62 & 248 & 39.62 \\
\hline Less Agree & 3 & 72 & 216 & 34.50 \\
\hline Disagree & 2 & 16 & 32 & 5.11 \\
\hline Strongly Disagree & 1 & 5 & 5 & 0.80 \\
\hline \multicolumn{2}{|c|}{ amount } & 180 & 626 & 100 \\
\hline
\end{tabular}

\section{Social Competence}

Based on data obtained from 18 respondents including principal and one of the teachers of the school, the indicators of social competence obtained total score of 125 with relative frequency $(21.44 \%)$ stated strongly agree, total score of 280 with relative frequency $(48.03 \%)$ agreed, then the total score of 141 with relative frequency $(24.19 \%)$ expressed a neutral / not hesitate, total score 34 with relative frequency $(5.83 \%)$ disagree, and with a total score of 3 with relative frequency $(0,51 \%)$ stated strongly disagree.

Table 3. Social Competence

\begin{tabular}{|l|c|c|c|c|}
\hline \multicolumn{1}{|c|}{ answer } & $\begin{array}{c}\text { Score } \\
(\mathrm{X})\end{array}$ & $\mathrm{F}$ & $\mathrm{FX}$ & $\begin{array}{c}\text { Relative } \\
\text { frequency }\end{array}$ \\
\hline Strongly agree & 5 & 25 & 125 & 21.44 \\
\hline Agree & 4 & 70 & 280 & 48.03 \\
\hline Neutral / Ragu & 3 & 47 & 141 & 24.19 \\
\hline Disagree & 2 & 17 & 34 & 5,83 \\
\hline Strongly Disagree & 1 & 3 & 3 & 0.51 \\
\hline \multicolumn{2}{|c|}{ Amount } & 162 & 583 & 100 \\
\hline
\end{tabular}

\section{Professional Competency}

Based on data obtained from 18 respondents including principal and one of the teachers of the school, the indicators of competence profesionl obtained a total score of 100 with relative frequency $(18.02 \%)$ stated strongly agree, the total score of 240 with relative frequency (43.24 $\%)$ agreed, then the total score of 171 with relative frequency $(30.81 \%)$ expressed a neutral / not hesitate, total score of 38 with relative frequency $(6.85 \%)$ disagree, and with a total score 56dengan relative frequencies (1, $08 \%$ ) stated strongly disagree.

Table 4. Professional Competence

\begin{tabular}{|l|c|c|c|c|}
\hline \multicolumn{1}{|c|}{ answer } & $\begin{array}{c}\text { Score } \\
(\mathrm{X})\end{array}$ & $\mathrm{F}$ & $\mathrm{FX}$ & $\begin{array}{c}\text { Relative } \\
\text { frequency }\end{array}$ \\
\hline Strongly agree & 5 & 20 & 100 & 18.02 \\
\hline Agree & 4 & 60 & 240 & 43.24 \\
\hline Neutral / Ragu & 3 & 57 & 171 & 30.81 \\
\hline Disagree & 2 & 19 & 38 & 6.85 \\
\hline Strongly Disagree & 1 & 6 & 6 & 1.08 \\
\hline \multicolumn{2}{|c|}{ amount } & 162 & 555 & 100 \\
\hline
\end{tabular}

\section{IV.DISCUSSION}

Based on the questionnaire that has been distributed to 18 respondents, obtained the degree of achievement of an overall score of $71.17 \%$. Figures show that the level of achievement of the general competence of teachers in the District of Lubuk Sikaping penjasorkes Pasaman quite good. Based on the analysis above to answer the research presented in the previous section turned out to be the competence of teachers in the district penjasorkes Lubuk Sikaping Pasaman showed good results. This is evident from the results obtained picture based on these indicators, will now be discussed with regard to the analysis. This discussion will be obtained with a clear picture of the results conducted.

\section{Pedagogic Competence}

Based on the level of achievement obtained penjasorkes teacher pedagogical competence level of $(74.89 \%)$. It can be concluded, for pedagogical competence indicator penjasorkes elementary teachers in the district of Lubuk Sikaping considered good.

\section{2. competence Personality}

Based on the level of achievement obtained penjasorkes level of competence of the teacher's personality $(69.33 \%)$. It can be concluded, for personal competence indicator elementary school teachers in the district penjasorkes Lubuk Sikaping considered good.

\section{Social Competence}

Based on the level of achievement obtained social competence levels of teachers penjasorkes by $(71.98 \%)$. It can be concluded, for indicators of social competence in the district elementary school teacher penjasorkes Lubuk Sikaping considered good.

\section{Professional Competence}

Based on the level of achievement obtained penjasorkes level of professional competence of teachers $(69.51 \%)$. It can be concluded, for the indicators of professional competence of teachers in the district elementary penjasorkes Lubuk Sikaping considered good.

\section{CONCLUSION}

Based on the results of this study physical education teacher's competence sports and health in primary schools in the District of Lubuk Sikaping Pasaman as follows:

1. From the results of data analysis and description of the results of pedagogical competence of teachers penjasorkes elementary schools subdistrict of Lubuk Sikaping Pasaman classified either.

2. From the results of data analysis and description of the results of the competence of the teacher's personality penjasorkes elementary schools subdistrict of Lubuk Sikaping Pasaman classified either.

3. From the results of data analysis and description of the results of social competence of elementary schools teachers penjasorkes subdistrict of Lubuk Sikaping Pasaman classified either.

4. From the results of data analysis and description of the results of the professional competence of teachers 
penjasorkes elementary schools subdistrict of Lubuk Sikaping Pasaman classified either.

\section{REFERENCES}

[1] Depdiknas. Undang-Undang Republik Indonesia No. 20 tahun 2005. Tentang Sistem pendidikan. Nasional. Jakarta : Cipta, 2003, pp.25.

[2] Syafruddin, Deswandi, Nurul, "Persepsi Siswa Terhadap Keterampilan Guru Dalam Pembelajaran Pendidikan Jasmani Olahraga Dan Kesehatan Di SDN 16 Pisang Kecamatan Pauh Kota Padang", Jurnal MensSana, [S.1.], v. 3, n. 1, p. 48-66, Juni, 2018.

[3] P. Achmad. "Manajemen Pendidikan Jasmani dan Olahraga". Jakarta: Rineka Cipta. 2012, pp. 35.

[4] H. Uno. "Profesi kependidikan". Jakarta: Bumi Aksara. 2011, pp. 34.

[5] Suwirman. "Dasar-dasar Penelitian". Padang: UNP Press. 2015, pp. 54. 